\title{
EKONOMI KERAKYATAN BERBASIS POTENSI LOKAL
}

\section{Fifi Hasmawati}

Dosen Fakultas Dakwah Dan Komunikasi UINSU Medan

\begin{abstract}
Abstraksi
Ekonomi kerakyatan dapat dikatakan suatu sistem yang berbasis pada kekuatan ekonomi rakyat. Karena ekonomi kerakyatan sendiri merupakan kegiatan perekonomi atau usaha yang dilakukan oleh rakyat kebanyakan yang secara swadaya mengelola sumberdaya ekonomi yang mampu diusahakan dan kuasainya, mereka mengharapkan bisa terpenuhi kebutuhan dasar keluarga dan tidak mengganggu kepentingan masyakarat sekelilingnya. Hal ini sering kita dengar dengan disebutkan Usaha Kecil dan Menengah (UKM). Konsep ekonomi kerakyatan dikembangkan sebagai usaha untuk lebih mengedepankan masyarakat untuk membangun kesejahteraandengan pemberdayaan masyarakat. Kemakmuran masyarakatlahyang diutamakan bukan kemakmuran orang perorang. Sebab itu perekonomian disusun sebagai usaha bersama berdasarkan atas asas kekeluargaan. Tujuan utama penyelenggaran dari sistim ekonomi kerakyatan adalah mewujudkan keadilan sosial bagi seluruh rakyat Indonesia melalui peningkatan kemmpuan masyarakat dalam mengendalikan jalannya roda perekonomian. Hal ini mampu menjangkau sasaran pokok ekonomi kerakyatan yaitu tersedianya peluang kerja dan penghiduan yang layak, sistim jaminan sosial bagi fakir miskin dan anak telantar, distribusi kepemilikan modal yang material relatif merata, pendidikan nasioanal secara cuma-cuma, dan kebebasan masyakat dalam mendirikan sektor ekonomi ataupun menjadi anggota serikat ekonomi.
\end{abstract}

Kata Kunci: ciri dan sistim ekonomi kerakyatan, tujuan dan penguat ekonomi kerakyatan

\section{A. Pendahuluan}

Pengertian ekonomi kerakyatan adalah sistem perekonomian yang di mana pelaksanaan kegiatan, pengawasannya, dan hasil dari kegiatan ekonomi dapat dinikmati oleh seluruh masyarakat. Ekonomi kerakyatan yang lainnya adalah suatu sistem perekonomian yang dibangun pada kekuatan ekonomi rakyat, ekonomi kerakyatan yaitu kegiatan dari ekonomi yang dapat memberikan kesempatan yang luas untuk masyarakat dalam berpartisipasi sehingga perekonomian dapat terlaksana dan berkembang secara baik.

Ekonomi kerakyatan adalah sistim perekonomian yang dibangun pada kekuatan ekonomi rakyat. Ekonomi kerakyatan adalah kegiatan yang memberikan kesempatan 
luas bagi masyarakat untuk turut berpartisipasi sehingga dapat terlaksana dan berkembang dengan baik.

Bung Hatta dalam Daulat Rakyat (1931) menulis artikel berjudul Ekonomi Kerakyatan dalam bahaya, sedang Bung Karno pada agustus 1930 dalam pembelaan di LandraadnBandung menulis nasib ekonomi rakyat berikut :

"Ekonomi Rakyat oleh sistim monopoli disempitkan, sama sekali didesak dan dipadamkan

Indonesia ekonomi kerakyatan adalah sistim ekonomi yang demokratis, seperti dalam penjelasan pasal 33 UUD 1945 yang berbunyi : ${ }^{2}$

"Produksi dikerjakan oleh semua untuk semua dibawah pimpinan atau pemilikan anggota-anggota masyarakat. Kemakmuran masyarakatlah yang diutamakan bukan kemakmuran orang perorang. Sebab itu perekonomian disusun sebagai usaha bersama berdasarkan atas asas kekeluargaan. Badengan swadayangun perusahaan yang sesuai dengan itu adalah koperasi. Perekonomian berdasarkan atas demokrasi ekonomi, kemakmuran bagi semua orang, sebab itu cabang-cabang produksi yang penting bagi negara dan yang menguasai hajat hidup orang banyak harus dikuasai oleh negara. Kalau tidak, tampuk produksi jatuh ke tangan oarang-orang yang berkuasa dan rakyat yang banyak ditindasinya. Hanya perusahaan yang tidak menguasai hajat hidup orang banyak boleh ada ditangan oarang perorang. Bumi dan air dan kekyaan yang terkandung di dalam bumi adalah pokok-pokok kemakmuran rakyat. Sebaba itu harus dikuasai oleh negara dan dipergunakan untuk sebesar-besarnya kemakmuran rakyat.

Dengan demikian ekonomi kerakyatan dapat dikatakan suatu sistim yang berbasis pada kekuatan ekonomi rakyat. Karena ekonomi kerakyatan sendiri merupakan kegiatan perekonomi atau usaha yang dilakukan oleh rakyat kebanyakan yang secara swadaya mengelola sumberdaya ekonomi yang mampu diusahakan dan kuasainya, mereka mengharapkan bisa terpenuhi kebutuhan dasar keluarga dan tidak mengganggu kepentingan masyakarat sekelilingnya. Usaha mereka biasanya meliputi perternakan, pertanian, perikanan, kerajinan, ataupun usaha makanan ciri khas dari daerah masing-masing. Hal ini sering kita dengar dengan disebutkan Usaha Kecil dan Menengah (UKM).

Menurut Prof.Dr. Mubyarto Ekonomi kerakyatan merupakan sistim yang berdasarkan kekeluargaan, kedaulatan rakyat dan menunjukkan pemihakan sungguh-sungguh pada ekonomi rakyat. Dalam prakteknya, ekonomi kerakyatan dapat dijelaskan juga sebagai ekonomi jejaring (network) yang menghubungkan sentra-sentra inovasi, produksi dan kemandirian usaha masyarakat kedalam suatu jaringan berbasis teknologi informasi untuk terbentuknya jejaring pasar domestik dan pelaku usaha masyarakat.

Pembangunan yang berorientasi kerakyatan dan berbagai kebijaksanaan yang berpihak pada kepentingan rakyat. Konsep ekonomi kerakyatan dikembangkan sebagai usaha untuk

\footnotetext{
${ }^{1}$ Soekarno, "Indonesia Menggugat", 1930:31

${ }^{2}$ UUD 1945, Pasal 33 (3).
} 
lebih mengedepankan masyarakat untuk membangun kesejahteraandengan pemberdayaan masyarakat.

\section{B. Ciri dan Sistem Ekonomi Kerakyatan}

Ekonomi kerakyatan adalah sistim ekonomi nasional yang disusun sebagai usaha bersama berdasarkan atas dasar kekeluargaan. Sebagaimana ditegaskan dalam UUD 1945 negara memainkan peranan penting dalam sistim ekonomi kerakyatan, melalui Badan Usaha Milik Negara, yang menguasai produksi hajat hidup orang banyak. Ciri dari sistim ekonomi kerakyatan adalah :

1. Peranan pemerintah yang menunjang terbentuk ekonomi kerakyatan, yang tidak saja terbatas sebagai penagtur jalannya roda perekonomian melalui badan usaha negara, tetapi tujuannya adalah untuk menjmin agar kemakmuran masyarakat senantiasa lebih diutamakan daripada kemakmuran orang seorang, dan agar tampuk produksi tidak jatuh ke tangan orang seoarang, yang memungkinkan ditindasnya rakyat banyak oleh segelintir orang yang berkuasa.

2. Efisiensi ekonomi berdasarkan keadilan, partisipasi dan berkelanjutan, kedua, mekanisme alokasi melalui perencanaan pemerintah, mekanisme pasar dan kerjasama.

3. Pemerataan penguasaan faktor produksi atau peningkatan kedaulatan ekonomi rakyat menjadi substansi sistim ekonomi kerakyatan.

4. Pola hubungan produksi kemitraan, sebagimana ditegaskan Bung Hatta pada koperasi tak ada majikan dan buruh, semuanya pekerja yang berkerjasama untuk menyelenggarakan keperluan bersama", ini menunjukan bahwa ekonomi kerakyatan tidak adanya individualistis dan kapitalistis. Kelima, kepemilikan saham oleh pekerja. Mekanisme pasarnya, alokasi juga didorong untuk diselenggarakan melalui usaha bersama koperasi. Mekanisme pasar koperasi sama dengan sistem ekonomi kerakyatan.

Dari Ciri sistem ekonomi kerakyatan dapat dipahami bahwa, 1. Negara atau pemerintah yang menguasai kebutuhan hidup masyarakat negara tersebut. Misalnya seperti: bahan bakar minyak, air dan sumber daya alam yang lainny, 2. Peran negara di ekonomi ini sangatlah penting akan tetapi tidak dominan, dan begitu juga peranan dari pihak swasta yang posisinya memang penting akan tetapi tidak mendominasi juga. Sehingga tidak mungkin terjadi kondisi sistem ekonomi liberal ataupun sistem ekonomi komando. Kedua pihak tersebut yaitu pemerintah dan juga pihak swasta hidup berdampingan secara damai dan saling mensupport satu sama lain, 3. Di dalam perekonomian ini masyarakat adalah bagian yang sangat penting, karena kegiatan produksi yang dilakukan, diawasi dan dipimpin oleh anggota masyarakat, 4. Buruh maupun modal tidak mendominasi perekonomian sebab ekonomi ini didasari atas asas kekeluargaan. 
Ada 4 alasan mengapa ekonomi kerakyatan perlu dijadikan paradigma baru dan strategi pembangunan ekonomi Indonesia, yaitu³:

1. Karakteristik Indonesia

Konsep pembangunan ekonomi yang dilakukan oleh negara-negara Eropa dan Amerika, diterapkan pada negara-negara berkembang memiliki hasil yang berbeda. Dengan mengandalkan dana pinjaman luar negeri untuk membiayi pembangunan, mengandalkan investasi dari luar negeri, memperkuat industri substitusi ekspor, selama dua sampai tiga dasarwarsa hasil mendorong pertumbuhan output nasional yang cukup luas bagi rakyat. Tapi negara-negara berkembang ternyata sangat rentan dengan terjadinya supply shock. Krisis mata uang Bath di Thailand, ternyata dengan cepat membawa Indonesia dalam krisis ekonomi dalm waktu yang singkat. Ini menunjukan konsep dan strategi pembangunan ekonomi yang berhasilditerapkan disuatu negera, belum tentu akan berhasil bila diterapkan pada negara lain. Teori pertumbuhan Harrod-domar, Rostow Solow dan David Romer dibangun dengan struktur masyarakat pelaku ekonomi yang berbeda dengan struktur ekonomi masyarakat Indonesia. Untuk itu membangun ekonomi Indonesia yang kuat, Stabil dan berkeadilan, tidak dapat menggunakan teori generik yang ada. Kita harus merumuskan konsep pembangunan ekonomi sendiri yang cocok dengan tuntutan politik rakyat, tuntutan konstitusi kita, dan cocok dengan kondisi obyektif dan situasi subyektif kita.

2. Konstitusi

Pasal 27 UUD 1945 bahwa setiap warga negara berhak untuk mendapatkan pekerjaan dan penghidupan yang layak. Pasal 33, bahwa ekonomi nasional disusun dalam bentuk usaha bersama yang berdasarkan kekeluargaan. Rumusan konstitusi kita yang menyangkut tata ekonomi yang seharusnya dibangun, belum cukup jelas, tapi dari sejarah sebenarnya makna dan ruh cukup jelas ${ }^{4}$.Ruh ekonomi usaha bersama atas asas kekeluargaan adalah tatanan ekonomi yang memberi kesempatan pada seluruh rakyat untuk berprestasi sebagai pelaku ekonomi. Dimana tatanan ekonomi seperti ini bukan berbentuk monopoli dan oligopoli ataupun monopsoni. Tatanan ekonomi nasional adalah tatanan ekonomi yang membedakan secara tegas barang dan jasa mana yang harus diproduksi oleh pemerintah dan yang mana harus diproduksi oleh sektor private. Dalam pasal 33 diinterprestasikan sebagai bentuk koperasi, tetapi koperasi yang harus menyesuaikan dengan perkembangan kebutuhan masyarakat dan lingkungan.

3. Empirik

Fakta menunjukkan bahwa krisis moneter yang berlanjut tehadap krisis ekonomi dan nilai tukar rupiah, ternyata tidak melumpuhkan perekonomian nasional. Dampak

${ }^{3}$ Hutomo, Mardi Yatmo, "konsep ekonomi kerakyatan", Http,www. Ekonomikerakyatan, diunduh tgl 26 november 2015, jam 9.30 wib

${ }^{4}$ UUD 1945 pasal 27 dan 33 
dari krisis ini memang benar bahwa ada kenaiknya harga barang pokok, inflasi hampir tidak dapat dikenalikan, ekspor menurun, impor barang modal menurun, produksi manufaktur menurun, dan pengangguran meningkat. Namun semua itu tidak berdampak terhadap perekonomian yang berpenghasilan bukan dari hitungan uang luar negeri, karena usaha mereka tidak menggunakan bahan impor, hampir tidak mengalami goncangan yang berarti.

4. Kegagalan Pembangunan Ekonomi

Selama kita mengalami krisis ekonomi sebanyak dua kali yaitu krisis hutang Pertamina dan krisis karena anjloknya harga minyak, rata-rata pertumbuhan ekonomi nasional masih diatas 6 persen pertahun. Berbagai program penanggulangan kemiskinan telah kita laksanakan, tapi belum mampu mengatasi masalah-masalah kemiskinan. Oleh sebab itu yang kita butuh bukan program pengentasan kemiskinan tapi strategi pembangunana yang cocok untuk Indonesia. Kalau strategi pembangunan ekonomi yang kita tempuh benar, maka sebenarnya semua program pembanguann adalah sekaligus menjadi program penanggulangan kemiskinan.

\section{Tujuan Ekonomi Kerakyatan}

Disamping itu ekonomi kerakyatan memiliki ciri tersebut, Indonesia memiliki sistim perekonomian nasional yang tumpuan mekanisme pasar berpegang teguh pada keadilan dengan prinsip adanya persaingan yang sehat. Dengan demikian seluruh masyarakat memiliki kesempatan yang sama untuk memperoleh pendapatan. Tujuan yang akan dicapai dari penguatan ekonomi kerakyatan adalah untuk melaksanakan amant konstitusi, khususnya mengenai ${ }^{5}$ :

1. Perwujudan tata ekonomi yang disusun yang disusun sebagai usaha bersama yang berasaskan kekeluargaan yang menjamin keadilan dan kemakmuran bagi seluruh rakyat Indonesia, sebagaimana tercantum dalam UUD 1945 ayat 1.

2. Perwujudan konsep Trisakti yaitu, berdikari dibidang ekonomi, berdaulat dibidang politik dan berkepribadian di bidang kebudayaan

3. Perwujudan cabang-cabang produksi yang penting bagi negara dan menguasai hajat hidup rakyat banyak dikuasai negara, tercantum pada UUD 1945 pasal 33 ayat 2 .

4. Perwujudan amanat bahwa tiap-tiap warga negara berhak atas pekerjaan dan penghidupan yang layak, tercantum pada UUD 1945 passal 27 ayat 2 .

Sedangkan untuk pencapaian tujuan khusus:

1. Membangun Indonesia yang berdikari secara ekonomi, berdaulat secara politik, dan berkepribadian yang berkebudayaan

${ }^{5}$ Mardi Yatmo Hutomo “Konsep Ekonomi Kerakyatan” htpp//wwwkonsep-.ekonomi-kerakyatan 
2. Mendorong pertumbuhan ekonomi yang berkesinambungan.

3. Mendorong pemerataan pendapatan rakyat dan

4. Meningkatkan efisiensi perekonomian secara nasioanal

Dengan melihat semua tujuan diatas maka ekonomi kerakyatan adalah watak dari ekonomi rakyat, dimana pemilikan asset ekonomi harus didistribusikan kepada sebanyakbanyaknya warga negara. Pendistribusian asset ekonomi kepada sebanyak-banyaknya kepada warga negara akan menjamin pendistribusian barang dan jasa secara adil, apabila terjadi ketidak merataan dalam distribusi barang dan jasa maka pasar akan mengalami kegagalan, tidak dapat mencapai effisensi yang optimal (pareto efficiency) dalam perekonomian, dan tidak ada invible hand yang dapat mengatur keadilan dan kesejahteraan. Teori ekonomi invisible hand merupakan teori yang di ajukan oleh Adam Smith (1776). Yang merupakan pakar ekonomi pada jaman itu. Sebenarnya inti dari ide Teori Ekonomi Invisible Hand adalah kompetisi diantara para distributor atau penjual dan pembeli yang akan menghasilkan relativitas atau kemungkinan terbaik dalam transaksi. karena hal itu dapat mendorong semua orang untuk melakukan kualifikasi dan peningkatan investasi sehingga yang akhirnya akan menghasilkan nilai lebih dengan tenaga kerja yang fixed atau tetap. Hasil praktis dari teori ekonomi invisible hand ini yang diaplikasikan pada jaman sekarang yaitu globalisasi alias pasar bebas. Globalisasi sendiri dimotori oleh Amerika Serikat yang menganut system kapitalis ini.

Menurutteori ekonomi invisible hand akan berjalan dengan baik apabila tidak ada yang kekuatan pemerintahan yang campur tangan. Karena masing-masing bidang baik yang kecil maupun yang besar akan bersaing dalam bidang masing-masing diluar monopoli.

Teori ekonomi Invisible hand sendiri dalam beberapa bidang juga ada atau setidaknya memiliki kesamaan karakteristik dalam beberapa bidang lain yang tidak dapat masuk dalam pemikiran manusia. Sebagai misal dalam bidang perikanan atau pertanian yang berkaitan dengan tanah. Tanah merupakan penghapus racun yang paling hebat dan alami, yang tidak bisa dibuat sintetisnya dalam teknologi yang paling canggih sekalipun (setidaknya untuk saat ini). Tanah yang memiliki keajaiban sendiri dalam menghisab atau mengolah bahan-bahan biologis sehingga mudah terurai dan dapat ditanami kembali atau di tebar benih kembali. Dalam dunia perikanan dikenal dengan pengolahan lahan kolam, hal ini agar sisa-sisa limbah pakan atau kotoran ikan terurai oleh mikroba dan masuk ke dalam tanah dan bisa subur kembali. Apabila dalam bidang Pertanahan pengolahan tanah digunakan agar semua pestisida atau pupuk hilang, sehingga tanah dapat kembali stabil, dalam artian tanah memiliki kemampuan untuk menjaga kestabilan dalam menghilangkan pestisida dan pupuk yang berlebih. Dan hal ini mirip dengan teori ekonomi invisible hand.

Dengan demikan dapat dilihat secara khusus bahwa tujuan dari ekonomi kerakyatan, diantaranya: 
1. Untuk membangun negara yang berdikari secara ekonomi, yang berdaulat secara politik, serta memiliki berkepribadian yang berkebudayaan,

2. Untuk mendorong pemerataan pendapatan masyarakat,

3. Dapat mendorong pertumbuhan perekonomi yang berkesinambungan,

4. Dan untuk meningkatkan efisiensi perekonomian nasional.

\section{Penguat Ekonomi Kerakyatan}

Ekonomi rakyat adalah ekonomi positif, yang menjelaskan bagaimana unit-unit produksi mengkombinasikan faktor-faktor produksi mengkombinasikan faktor-faktor produksi untuk menghasilakn barang private dan jasa private dan distribusikan barang dan jasa dimaksud pada konsumen, sehingga diperoleh keuntungan yang maksimal bagi produksen, dan utility yang maksimal bagi konsumen.

Tata ekomomi rakyat tidak mempermasalah keadilan baik pada proses produksi maupun distribusinya, lain halnya dengan ekonomi kapitalis liberal, tidak dipermasalahkan apakah asset ekonomi dimiliki oleh puluhan orang juga tidak mempermasalahkan barang dan jasa private hanya dinikmati oleh sedikit atau banyak warganya, karena ekonomi ini terbentuk dalam dua kelompok tenaga kerja dan pemilik modal. Mereka menyakoni bahwa keadilan dan kesejahteraan warganya akan dapat terciptakan keadilan dan pemerataan melalui mekanisme pasar. Ada invisible hand yang akan menciptakan keadilan dan pemerataan , invisible hand ini adalah kekuatan dan hukum yang ada dalam pasar, karenanya tidak perlu intervensi pemerintah dalam perekonomian barang private. Tugas pemerintah hanyalah bagaimana menjamin mekanisme asar berjalan dan menyediakan barang dan jasa publik. Mekanisme pasar dengan kekuatan invisible hand yang dapat menjamin pemerataan dan keadilan ekonomi masyarakat ternyata mengalami kegagalan. Kemudian muncul antitesis dari tata ekonomi kapitalisme liberal yaitu tata ekonomi etatisme atau ekonomi sosialis komunis. Ekonomi sosialis komunis proses produksi dan distribusi harus diatur oleh pemerintah untuk menjamin pemerataan dan keadilan, dalam ekonomi ini diyakini hanya pemerintah sebagai representasi rakyat, yang tidak memiliki interest, yang dapat menjamin keadilan baik dalam proses produksi maupun distribusi.

Ekonomi kerakyatan adalah watak dan tatanan ekonomi dimana, pemilikan asset ekonomi harus didistribusikan kepada sebanyak-banyak warga negara. Pendistribusian asset ekonomi kepada sebanyaknya warga negara yang akan menjamin pendistribusian barang dan jasa kepada sebanyak-banyak warga secara adil. Dalam pemilikan asset yang tidak adil dan merata, maka pasar akan selalu mengalami kegagalan, tidak akan dapat dicapai efisiensi yang optimal (Pareto Effisensi) dalam perekonomian, tidak ada invisible hand yang dapat mengatur keadilan dan kesejahteraan. Fakta menunjukkan pemerintah gagal memposisikan sebagai wakil rakyat yang tidak memiliki interst dan gagal dalam merubah barang private sebagai barang publik. Karenanya dalam ekonomi kerakyatan 
tetap menempatkan pemerintah sebagai penyedia barang publik dan jasa publik. Intervensi pemerintah dalam ekonomi rakyat hanya diperlukan untuk menamin mekanisme distribusi aset terjadi melalui mekanisme pasar.

Ekonomi kerakyatan adalah tatanan ekonomi dimana aset ekonomi dalam perekonomian nasional didistribusian kepada sebanyak-banyaknya warga negara. Dengan demikian ekonomi kerakyatan penguat bagi :

1. Tata ekonomi yang dapat memberikan jaminan pertumbuhan out put perekonomian suatu negara secara mantap dan berkesinambungan, dan dapat memberikan jaminan keadilan bagi rakyat.

2. Tata ekonomi yang dapat menjamin pertumbuhan output secara mantap atau tinggi adalah tata ekonomi yang sumber daya ekonominya digunakan untuk memproduksi jasa dan barang pada tingkat pareto optimum.tingkat pareto optomum adalah tingkat penggunaan faktor-faktor produksi secara maksimal dan tidak ada faktor produksi yang ngangur atau idle.

3. Tata ekonomi yang dapat menjamin pareto optimum adalah tata ekonomi yang mampu menciptakan penggunaan tenaga kerja secara penuh (full employment) dan mampu menggunakan kapital atau modal secara penuh

4. Tata ekonomi yang dapat memberikan jaminan keadilan bagi rakyat tata ekonomi yang pemilikan aset ekonomi nasional terdistribusi secra baik kepada seluruh rakyat, sehingga sumber penerimaan (income) rakyat tidak hanya dari penerimaan upah tenaga kerja, tetapi juga sewa modal dan dividen. Secara ekonomis, dalam perekonomian kerakyatan, model income masyarakat adalah $Y_{1}=(W+\partial+i s)$. Dimana $Y_{1}$ adalah income individu, W adalah penerimaan dari upah tenaga kerja, ð adalah penerimaan deviden atau bagi hasil usaha, i adalah tingkat sewa modal ( misalnya deposito), dan s adalah jumlah tabungan atau endowment yang disewakan. Dengan demikian dalam tata ekonomi kerakyatan, masyarakat bukan hanya sebagai buruh dalam perekonomian tetapi juga pemilik atau memiliki saham di sektor produksi.

Berdasarkan tata ekonomi kerakyatan maka dapat dilihat bahwa ada beberapa kelebihan dari sistem ekonomi kerakyatan yaitu:

1. Rakyat yang kurang mampu bisa mendapatkan perlakuan hukum yang sama atau secara adil dalam masalah perekonomian.

2. Dapat memberikan perhatian yang lebih pada rakyat kecil melalui berbagai macam program operasional yang nyata.

3. Sistem ekonomi ini dapat mewujudkan kedaulatan rakyat.

${ }^{6}$ Ibid, akses 20/1/2016, 13.32 wib 
4. Dapat merangsang kegiatan ekonomi yang lebih produktif di tingkat rakyat sekaligus dapat melahirkan jiwa kewirausahaan.

5. Transaksi antara produksi, distribusi dan konsumsi sangat baik.

6. Hubungan antara produksi, distribusi dan juga konsumsi akan saling membutuhkan dan sangat baik.

Namun di balik ada kelebihan perlu juga untuk membenahi sistem tata ekonomi kerakyatan, yang justru akan menjadi kelemahan dari tata ekonomi ini:

1. Dalam ekonomi ini akan terjadi praktek membagi-bagi uang kepada rakyat, peraktek ini sangat tidak menguntungkan bagi pihak manapun, termasuk rakyat itu sendiri.

2. Aksi membagi-bagi uang ini secara tidak sadar dapat menyebabkan usaha mikro atau kecil dan menengah serta koperasi yang selama ini tidak berdaya dapat bersaing dalam suatu mekanisme pasar, biasa menjadi sangat bergantung pada aksi tersebut.

3. Masih kurangnya pengetahuan rakyat mengenai Investasi, akibatnya dapat menyebabkan kemiskinan terlalu lama atau perputaran roda yang lambat.

4. Kurangnya penerapan dari manajemen.

5. Tidak adanya dukungan yang optimal dari pemerintah, meskipun peran pemerintah sangat penting tapi tidak dominan.

Sistem ekonomi kerakyatan tidak hanya berhenti pada tingkat wacana, sejumlah agenda kongkrit ekonomi kerakyatan harus segera diangkat kepermukaan. Secara garis besar dalam lima agenda pokok ekonomi kerakyatan yang harus segera diperjuangkan. Kelima agenda tersebut merupakan inti dari politik ekonomi kerakyatan dan menjadi titik masuk (entry point) bagi terselenggaranya system ekonomi kerakyatan dan dalam jangka panjang. Kelima hal tersebut adalah ${ }^{7}$ :

1. Penghapusan monopoli melalui penyelenggaraan mekanisme.

2. Persaingan yang berkeadilan (Fair competition).

3. Peningkatan alokasi sumber penerimaan Negara kepada pemerintah daerah.

4. Penguasaan dan redistribusi pemilikan lahan pertanian kepada petani penggarap.

5. Pembaharuan UU Koperasi dan pendirian koperasi dalam berbagai bidang usaha dan kegiatan.

Hal yang perlu dicermati adalah peningkatan kesejahteraan rakyat dalam konteks ekonomi kerakyatan tidak didasarkan paradigma lokomotif, melainkan pada paradigma fondasi. Artinya,peningkatan kesejatehraan tidak lagi bertumpu pada dominasi pemerintah pusat, modal asing dan perusahaan konglomerasi, melainkan pada kekuatan pemerintah

${ }^{7}$ Dr. H. Abd. Rahman Rahim, SE, "Sistem Ekonomi Kerakyatan dan Daya Saing Ekonomi Daerah" disampaikan pada acara Seminar Nasional di Auditorium Al-Amien Unismuh Makassar. Senin $18 \mathrm{Maret}$ 2013 
daerah, persaingan yang berkeadilan, usaha pertanian rakyat, peran koperasi sejati, yang diharapkan mampu berperan sebagai fondasi penguatan ekonomi rakyat.Strategi pembangunan yang memberdayakan ekonomi rakyat merupakan strategi melaksanakan demokrasi ekonomi yaitu produksi dikerjakan oleh semua pimpinan dan peilikan anggota masyarakat. Kemakmuran masyarakat lebih diutamakan ketimbang kemakmuran perorangan. Maka kemiskinan tidak dapat ditoleransi sehingga setiap kebijakan dan program pembangunan harus member manfaat pada mereka yang paling miskin dan paling kurang sejahtera. Inilah pembangunan generasi mendatang sekaligus memberikan jaminan sosial bagi yang paling miskin dan tertinggal.

Setiap daerah mempunyai corak pertumbuhan ekonomi yang berbeda dengan daerah lain. Oleh sebab itu perecanaan pembangunan ekonomi suatu daerah pertama-tama perlu mengenai karakter ekonomi, sosial dan fisik daerah itu sendiri, termasuk interaksinya dengan daerah lain. Dengan demikian tidak ada strategi pembangunan ekonomi daerah, baik jangkah pendek maupun jangka panjang. Pemahaman mengenai teori pertumbuhan ekonomi wilayah yang dirangkum dari kajian terhadap pola-pola pertumbuhan ekonomi dari berbagai wilayah, merupakan satu factor yang cukup menentukan kualitas rencana pembangunan ekonomi daerah. Daya saing (competitiveness) merupakan salah satu kata kunci yang lekat dengan pembangunan ekonomi local/daerah. Camagnni (2002) mengungkapkan bahwa daya saing daerah kini merupakan salah satu isu sentral, terutama dalam rangka mengamankan stabilitas ketenagakerjaan, dan memnafaatkan integrasi eksternal (kecenderungan global), serta keberlanjutan pertumbuhan kesejahteraan dan kemakmuran lokal. Daya saing tempat (loyalitas dan daerah) merupakan kemampuan ekonomi dan masyarakat lokal untuk memberikan peningkatan standar hidup bagi warga (Malecki, 1999). Daya saing merupakan kemampuan menghasilkan produk barang dan jasa yang memenuhi pengujian internasional, dan dalam saat kemampuan daerah menghasilkan tingkat pendapatan yang tinggi dan kebelanjutan, atau kemampuan daerah menghasilkan tingkat pendapatan dan kesempatan kerja yang tinggi dengan tetap terbuka terhadap persaingan eksternal (European Commission, 1999).

Terkiat dengan optimalisasi ekonomi kerakyatan, jelas akan memicu peningkatan daya saing daerah, karena jika telah berdaulat secara ekonomi maka daerah itu akan cukup kokoh menahan gempuran goncangan ekonomi eksternal.

\section{E. Kesimpulan}

Ekonomikerakyatanberbasispotensilocal ialahtatanan ekonomi dimana aset ekonomi dalam perekonomian nasional didistribusian kepada sebanyak-banyaknya warga negara, dengansistem yang berbasis pada kekuatan ekonomi rakyat. Secara garis besar dalam lima agenda pokok ekonomi kerakyatan yang harus segera diperjuangkan, kelima hal tersebut adalah : 
1. Penghapusan monopoli melalui penyelenggaraan mekanisme.

2. Persaingan yang berkeadilan (Fair competition).

3. Peningkatan alokasi sumber penerimaan Negara kepada pemerintah daerah.

4. Penguasaan dan redistribusi pemilikan lahan pertanian kepada petani penggarap.

5. Pembaharuan UU Koperasi dan pendirian koperasi dalam berbagai bidang usaha dan kegiatan. 


\section{DAFTAR PUSTAKA}

Abd. Rahman . H. Abd.Rahim, (2013), Wakil Rektor I Unismuh Makassar "Sistem Ekonomi Kerakyatan dan Daya Saing Ekonomi Daerahdisampaikan pada acara Seminar Nasional di Auditorium Al-Amien Unismuh Makassar. Senin 18 Maret 2013

Carnoy, M. And Shearer D. (1980), Economic Democracy: The Challenge of 1980s, M.E. Sharpe, New York

Baswir.Revrisond,(2006) "Ekonomi Kerakyatan", Makalah untuk Seminar Bulanan Pusat Studi Ekonomi Kerakyatan-UGM, tanggal 18 Mei 2006

Dahl, Robert A. (1992), Demokrasi Ekonomi: Sebuah Pengantar (diterjemahkan oleh Ahmad Setiawan Abadi), Yayasan Obor Indonesia, Jakarta.

http/s://succesarry.wordpress.com/sistim-ekonomi-kerakyatan/ mardiyatmohutomo. Diakses 22/2/2016, pukul 15.15 wib

Hatta, Mohammad (1928), Indonesia Merdeka, diterbitkan kembali tahun 1976, Bulan bintang, Jakarta

(1932), Ke Arah Indonesia Merdeka, diterbitkan kembali dalam bentuk edisi khusus tahun 1994, Dekopin, Jakarta

Poole, Michael. (1989), The Origins of Economic Democracy, Routledge, London

Smith, J.W (2003), Economic Democracy: The political Struggle of the 21st Century, 3rd edition, Institute for Economic Democracy and Institute for Cooperative Capitalsm, New York

Sugihono, Muhadi (1999) Kritik Antonio Gramsci Terhadap Pembangunan Dunia Ketiga, Pustaka Pelajar, Yogyakarta

Woodworth, Warner P(2002) Economic Democracy: Essay and Research on Workers' Empowerment, Sledgehammer Perss, Pittsburg 